\title{
Hajj, Civilization and Islamic Banking Contribution Discourses
}

\author{
Lucky Nugroho $^{1}$, Akhmad Amien Mastur $^{2}$, Fardinal $^{3}$, Yananto Mihadi Putra ${ }^{4}$ \\ \{lucky.nugroho@mercubuana.ac.id ${ }^{1}$, amien_mastur@yahoo.co.id ${ }^{2}$, fardinal@mercubuana.ac.id ${ }^{3}$, \\ yananto.mihadi@mercubuana.ac.id $\left.{ }^{4}\right\}$ \\ Universitas Mercu Buana, Indonesia ${ }^{134}$, Program Doktoral Universitas Trisakti (Islamic Economics \\ and Finance $)^{2}$
}

\begin{abstract}
The aim of this conceptual paper is to find out how Hajj and Islamic banks can contribute to the realization of noble civilization. This research is a conceptual paper with qualitative methods supported by data and information from the scientific literature of previous research. The discussion of conceptual papers is limited by the following research questions (1) What are the benefits of early Hajj? (2) What is the relationship between the intention of pilgrimage from an early age to noble civilization?; (3) What is the role of Islamic banking in enhancing noble civilization? Civilization is an inseparable aspect of Islam. Therefore the effort to reach a civilized society is through the contribution of the younger generation, one of the ways is the hajj in the productive age and the availability of support from Islamic banking which provides products and services following Islamic principles.
\end{abstract}

Keywords: Hajj, Islamic Banking, Civilization.

\section{Background}

The phenomenon of the many corruptions and immoral actions in society today shows the lack of spiritual values held by the community. Furthermore, Indonesia is a country with the largest Muslim population in the world. It is a model for other countries that Indonesia is a country with a Muslim majority that can maintain peace and democracy, while Indonesia is not a country based on Islamic law (1). Even when referring to Hillary Clinton's statement "Learn Islam to Indonesia", it shows that Indonesia can be an example of how the existence of the majority of Muslims can maintain the pluralism of peace of life as a nation and state, when compared to other countries that have a majority Muslim population and even countries based on Islamic law (2). This shows a lower spirituality than Muslims in Indonesia, also though the numbers are significant, but in applying Islamic values in a kaffah or in totality is still low (3) . Then based on data from the Corruption Perceptions Index (CPI) in 2018, Indonesia's ranking in the Asia Pacific region is still below that of Asian countries such as Brunei Darussalam, Taiwan, South Korea, Malaysia, India and China (Table 1). 
Table 1. Corruption Ratings in Several Countries in the Asia Pacific Region in 2018

\begin{tabular}{|l|l|l|}
\multicolumn{2}{l}{ SCORE COUNTRY/TERRITORY } & RANK \\
\hline 87 & New Zealand & 2 \\
\hline 85 & Singapore & 3 \\
\hline 77 & Australia & 13 \\
\hline 76 & Hong Kong & 14 \\
\hline 78 & Japan & 18 \\
\hline 68 & Bhutan & 25 \\
\hline 68 & Brunei Darussalam & 31 \\
\hline 68 & Taiwan & 31 \\
\hline 57 & Korea, South & 45 \\
\hline 47 & Malaysia & 61 \\
\hline 46 & Vanuatu & 64 \\
\hline 44 & Solomon Islands & 70 \\
\hline 41 & India & 78 \\
\hline 39 & China & 87 \\
\hline 38 & Indonesia & 89 \\
\hline
\end{tabular}

Source: (4)

Nonetheless, conditions in 2018 have improved compared to the conditions in 2014, where, according to CPI Indonesia is ranked 107th so that the performance of the Indonesian government in the commitment to eradicate corruption has succeeded in raising Indonesia's ranking in the Asia Pacific region. The number of Indonesians who are rated the 4th largest in the World and the majority of the population is 85\% Muslim. In 2010 the middle class population was based on Bank Indonesia (BI) data of 56,5\% (5), from the total population of Indonesia. According to statistics from the Central Statistics Agency in 2010, the total population of Indonesia was 237.641.326 people so that the number of Muslims reached 201.995.127 people (85\%) and the population of the middle category in Indonesia reached 134.267.349 people (56.5\%). With the fundamentals of the largest act of Muslims and a large number of middle class people in Indonesia, it is appropriate and appropriate for Muslims to become the locomotive of the revival of noble civilization in the world.

Furthermore, with a Muslim-majority state, another condition that also distinguishes Indonesia from other Muslim countries is that Indonesia is the country that sends the largest number of pilgrims in the world $(6,7)$. This indicates that the population of Indonesia has the potential to increase emotional and spiritual intelligence (morals) or become Muslims who have faith and piety. In Islam, the order of Islamic pillars includes: (i) Saying of the Creed; (ii) Establishing Sholat; (iii) Fasting in the Month of Ramadan; (iv) Implementing of Zakat; (v) Hajj if able. Pilgrimage is part of the last Islamic law so that the pilgrimage can be construed as worship that perfects the faith and piety because it has been forged with other worship (8). The execution of the hajj pilgrimage is certainly inseparable from the financial services of Islamic banking, because the storage of money for the purpose of the hajj pilgrimage must be kept in a sharia bank:

- To find out the benefits of intending Hajj since early; 
- To find out the early intention of the pilgrimage to the noble civilization;

- To find out the role of Islamic banking to enhance noble civilization..

\section{Method}

The purpose of this conceptual paper is to provide additional insights to academics and practitioners and stakeholders in order to increase the impact of the pilgrimage to the welfare of society. Founded on these objectives, the research method used in this study is qualitative, supported by data and analysis of studies that have been conducted by previous researchers. The aim of this conceptual paper is to provide additional insights to academics and practitioners and stakeholders in order to increase the impact of the pilgrimage to the welfare of society:

- What are the benefits of intending Hajj since early?;

- What is the relationship of the intention of early pilgrimage with noble civilization ?;

- What is the role of Islamic banking in promoting noble civilization?.

\section{Discussion}

In this conceptual paper, the discussion is the data and analysis of studies related to the impact of the Hajj pilgrimage on productive age and the role of Islamic banking in realizing a noble civilization. The elaboration of the research questions above is as follows:

\subsection{Intention to Hajj since Early Stage (young age)}

These actions depend on the intention, and everyone will acquire what they intend, the intention is something to be achieved that gives birth to right business actions and behavior, it is also listed from several hadiths and verses of the Qur'an as follows (9): Meaning: "Say, "O my people, work according to your position, [for] indeed, I am working; and you are going to know (Surah Az-Zumar verse 39)." The verse tells and motivates us to work. By working we not only earn income and can meet needs, but also to make a living which is part of worship. A Muslim must work with sincere intentions because Allah SWT.

From Umar radhiyallahu 'anhu, that the Prophet sallallaahu' alayhi wa sallam said, "Charity depends on the intention, and someone only gets according to his intention. Whoever migrates to Allah and His Messenger, then migrates to Allah and His Messenger, and whoever migrates because of the world or because of the woman he wants to marry, then the migration is according to where he migrates. "(Narrated by Bukhari, Muslim , and four Imam of Hadith Experts); From Ibn 'Abbâs Radhiyallahu anhu from the Prophet sallallaahu' alayhi wa sallam about the hadith that he narrated from his Rabb Azza wa Jalla. The Prophet sallallaahu 'alayhi wa sallam said," Verily Allah writes the virtues and mistakes and then explains them. Whoever intends to do good, but he does not (do) do it, Allah keeps writing it as perfect goodness on His side. If he intends to do good deeds and then do it, then Allah writes it on His side as ten goodness up to seven hundred times too many multiples. Whoever intends to do bad, but he does not do it, then Allah writes it on His side as perfect goodness. And whoever intends to make a mistake then does it, Allah writes it as a mistake." (HR. al-Bukhâri Muslim).

According to the QS. At-Tur verse 21, meaning: " And those who believed and whose descendants followed them in faith - We will join with them their descendants, and We will 
not deprive them of anything of their deeds. Every person, for what he earned, is retained." In this verse, the role of youth as the next generation is very important in Islam.

According to QS. Al-Maidah verse 54, meaning: " O you who have believed, whoever of you should revert from his religion - Allah will bring forth [in place of them] a people $\mathrm{He}$ will love and who will love Him [who are] humble toward the believers, powerful against the disbelievers; they strive in the cause of Allah and do not fear the blame of a critic. That is the favor of Allah ; He bestows it upon whom He wills. And Allah is all-Encompassing and Knowing." Following the verse, the youth have a role as a substitute generation.

According QS. Maryam verse 42 as follows "[Mention] when he said to his father, "O my father, why do you worship that which does not hear and does not see and will not benefit you at all?. Futhermore according to QS Al Kahfi verse 18 as follows: "And you would think them awake, while they were asleep. And We turned them to the right and to the left, while their dog stretched his forelegs at the entrance. If you had looked at them, you would have turned from them in flight and been filled by them with terror." Youth groups who believe in Allah SWT and leave the majority of their people who deviate from the religion of Allah SWT, Allah SWT saved these youths and put them to sleep for 309 years until the end of the pagan regime into a regime of faith.

Youth are the next generation of the nation (10). In the perspective of Islam, the next generation is the generation of the faithful and devoted to Allah SWT and has the noble character, which includes ethics, morals, integrity, spiritual or understanding, and practice of religious values in daily life. This is one form of "amar makruf nahi munkar," which is to carry out the commands of Allah SWT and stay away from His prohibitions.

\subsection{Early Hajj Intention and Noble Civilization}

Civilization is often used as a synonym for the word "culture (moral)." In the same sense, civilization can mean "improvement of thought, manners, or taste." Referring to the number of immoral events, corruption which also contradicts Islamic values, a joint effort from all parties is needed to find a solution to create a noble civilization. The next question is whether the intention to make Hajj since early can be used as one solution? The intention is a positive energy that generates a person's big dreams, and big dreams will evoke the spirit of business activity strategies to achieve the goal, which is to perform the pilgrimage. Hajj is ritual worship for Muslims who can materially, physically, and scientifically to do certain deeds at a predetermined time and place. Islam and civilization are a unity that is impossible to separate because Islam aims to create a knowledgeable social life (al-fikriyyah) that is based on spirituality, morals, and ethics to create a civil society (11). Related to the definition of the intention of the pilgrimage, there are benefits both when the person intends to perform the pilgrimage and after the pilgrimage. Some positive benefits arising from the intention of Hajj since an early age (young age), among others:

- The money used to pay the hajj pilgrimage is mandatory from sources and lawful ways of obtaining it, so the condition is reminiscent of candidates who have intended to make Hajj at a young and productive age to be able to sort out and choose income, which is categorized as halal and haram sources and how to get it;

- From the beginning, those who had intended to make the pilgrimage early on had also made self-introspection or made repentance, both from small and large sins. Awareness of self-introspection and distance from small and large sins can prevent them from immoral acts, violate ethics, and are prohibited by religion, including avoiding corruption.

Furthermore, other benefits that arise are lessons after the Hajj at a productive age. In 
accordance with the assumptions above if they have made the intention of hajj at the age of 25 years old, then their age when hajj at the age of 40 years old. At the age of 40 years old are still included in the productive age range, therefore they have great potential to be able to play a role and be able to influence the environment of their homes, workplaces, and families to implement Islamic values in their lives. Some of the hadiths and verses of the Qur'an relating to the Hajj are as follows:

- Hajj through wealth that has been given by Allah SWT. "And proclaim to the people the Hajj [pilgrimage]; they will come to you on foot and on every lean camel; they will come from every distant pass. That they may witness benefits for themselves and mention the name of Allah on known days over what He has provided for them of [sacrificial] animals. So eat of them and feed the miserable and poor." (QS Al-Hajj verse 27-28).

- The requirement to reach the Mabrur pilgrimage is to have clean property. "Pilgrimage with halal sustenance is due to the Prophet sallallaahu 'alaihi wa sallam said Allah is thoyyib (good) and does not accept except from the good" (HR. Muslim no. 1015).

- Hajj Mabrur the reward in heaven. From Abu Hurairah radhiyallahu 'anhu, he said, "The Prophet sallallaahu' alaihi wa sallam was asked," What is the best practice "He is sallallaahu 'alaihi wa sallam replied," Faith in Allah and His Messenger. " There are those who ask again, "Then what else?" He sallallaahu 'alaihi wa sallam replied, "Jihad in the way of Allah." Some ask again, "Then what else?" "Hajj Mabrur," answered the Prophet sallallaahu' alaihi wa sallam. "

\subsection{Islamic Bank Contribution}

The effort to perfect Islamic life is by balancing intellectual, emotional, and spiritual (fiqh and moral) elements in social life (worship and muamallah). The existence of Islamic Banks in Indonesia must be able to offer a vision of how they should develop Islamic banking in Indonesia as the main driver of the Indonesian economy (12-14). Also, Islamic banks should offer products that have a long-term impact and implications on civilization. The definition of sustainable is the activities, programs, and products that have an impact not only at this time but also for future generations, and for environmental sustainability, in other words, the benefits not only are enjoyed by the current generation but can also be felt by generations next generation (15-17). Related to the phenomenon of moral decline and the number of corruption cases in Indonesia, Islamic banks should be able to offer products and services that have positive implications for moral degradation, such as corruption. One such program is to motivate the general public and the younger generation, in particular, to intend to go on pilgrimage early on. The motivation for the community can be in the form of a smart campaign. Through this program, it is hoped that they have started to have plans and intend to go on hajj since an early age, which is performing pilgrimage at a productive age so that they can play a role, and contribute to giving more significant implications and positive impacts on the life of the nation and state in Indonesia."

\section{Conclusion}

Civilization and Islam are a unity that cannot be separated. Islam is a comprehensive religion that regulates all aspects of life. Therefore, the manifestation of Islamic teachings, the 
realization of a civilized society is a society that has the knowledge, good character, morals, and morality. One of these efforts can be pursued through the implementation of the sixth pillar of Islam, namely the pilgrimage, if able. By carrying out the pilgrimage from an early age or at a productive age, it is hoped that the next generation of Muslim youths will be able to contribute more to the realization of a civilized and civilized society. Also, Islamic banking institutions, as supporting financial transactions, must contribute to creating a civilized society through sharia financial literacy, namely through services and products that are following sharia principles (maqasid syariah)

\section{References}

1. Hakiki KM. Islam dan Demokrasi: Pandangan Intelektual Muslim dan Penerapannya di Indonesia. J Ilm Agama dan Sos Budaya. 2016;1(1):1-17.

2. Hamid AL. Politik Identitas Agama Lokal Studi tentang Aliran Kepercayaan Perjalanan Ciparay Bandung. al-Afkar, J Islam Stud [Internet]. 2018;2(1):113-30. Available from: https://alafkar.com/index.php/Afkar_Journal/article/view/22

3. Nubowo A. Islam dan Pancasila di Era Reformasi : Sebuah Reorientasi Aksi. J Keamanan Nas. 2015;1(1):61-78.

4. Transparency International. Corruption perceptions [Internet]. 2018. Available from: http://cpi.transparency.org/cpi2013/results/

5. 60\% Penduduk Indonesia Kelas Menengah - Investor.ID [Internet]. Antara. 2013 [cited 2019 Dec 8]. Available from: https://investor.id/archive/60-penduduk-indonesia-kelas-menengah

6. Rachmadi A. Studi Tentang Rekrutmen Calon Jamaah Haji Dalam Keberangkatan ke Saudi Arabia di Kantor Kementerian Agama Kota Samarinda. eJournal Ilmu Pemerintah. 2014;2(2):2372-86.

7. Bruinessen M Van. Mencari Ilmu dan Pahala di Tanah Suci : Orang Nusantara Naik Haji. Ulumul Quran. 2017;2(5):42-9.

8. Abidin Z. Rahasia Hukum Islam dalam Ruang Peribadatan. J Adab. 2017;XII(23):23-35.

9. Anoraga B, Prasetyo A. Motivasi Kerja Islam dan Etos Kerja Islam Karyawan Bank Jatim Syariah. J Ekon Syariah Teor dan Terap. 2015;2(7):531-41.

10. Taubah M. PENDIDIKAN ANAK DALAM KELUARGA PERSPEKTIF ISLAM Mufatihatut Taubah (Dosen STAIN Kudus Prodi PAI). J Pendidik Agama Islam. 2016;3(1):109-36.

11. Dzulhadi QN. Islam sebagai Agama dan Peradaban. Tsaqafah. 2015;11(1):152-68.

12. Nugroho L, Chandra Husnadi T, Utami W, Hidayah N. Maslahah and Strategy To Establish a Single State-Owned Islamic Bank in Indonesia. Tazkia Islam Financ Bus Rev. 2017;10(1):1733.

13. Nugroho L, Utami W, Sukmadilaga C, Fitrijanti T. The Urgency of Allignment Islamic Bank to Increasing the Outreach (Indonesia Evidence). Int J Econ Financ Issues. 2017;7(4):283-91.

14. Nengsih N. Peran Perbankan Syariah Dalam Mengimplementasikan Keuangan Inklusif di Indonesia. Etikonomi. 2015;14(2):221-40.

15. Nugroho L, Badawi A. The Islamic Banking, Asset Quality: "Does Financing Segmentation Matters" (Indonesia Evidence). Mediterr J Soc Sci. 2018;9(5):221-35. 
16. Nugroho L, Badawi A, Hidayah N. Discourses of sustainable finance implementation in Islamic bank (Cases studies in Bank Mandiri Syariah 2018). Int J Financ Res. 2019;10(6):108-17.

17. Nugroho L, Utami W, Doktoralina CM. Ekosistem Bisnis Wisata Halal dalam Perspektif Maqasid Syariah (Halal Tourism Business Ecosystem in the Maqasid Syariah Perspective). Perisai Islam Bank Financ J. 2019;3(2):84-92. 